\title{
Intraspecific competition as a driver for true production potential of soybean
}

\author{
Agnieszka Klimek-Kopyra, ${ }^{1}$ Magdalena Bacior, ${ }^{2}$ Anna Lorenc-Kozik, ${ }^{1}$ \\ Reinhard W. Neugschwandtner, ${ }^{3}$ Tadeusz Zając ${ }^{1}$ \\ ${ }^{1}$ Department of Agroecology and Plant Production, University of Agriculture in Kraków, Kraków, Poland; \\ ${ }^{2}$ Department of Soil Science and Agrophysics, University of Agriculture in Krakow, Kraków, Poland; \\ ${ }^{3}$ Institute of Agronomy, Department of Crop Sciences, University of Natural Resources and Life Sciences \\ Vienna (BOKU), Tulln, Austria
}

\begin{abstract}
Highlights
- It is recommended to increase the sowing density in areas with less rainfall to compensate number of pods and number of seeds.

- Low intraspecific competition increased yield and nitrogen accumulation in the seeds as the plant density increased.

- In the wet year, strong intraspecific competition resulted in high yield and nitrogen accumulation only up to a density of 42 plants $m^{-2}$.

- At very low crop density, the intensity of intraspecific competition is very low and blocked the manifestation of the plants' true production potential.

- In the dry year, nitrogen uptake of soybean increased with plant density in the canopy up to the maximum density.
\end{abstract}

\begin{abstract}
Phenotypic plasticity of agricultural plants is considered to be one of the main means by which plants cope with the variability of environmental factors. A major contributor to plant plasticity is sowing density, which has a relevant impact on competitive intensity concerning plant density in different environments (CI) and absolute severity of competition (ASC) concerning plant-plant responses to each other in canopy. A field experiment with soybean was set up at the Experimental Station in Prusy, Krakow, to determine the impact of intraspecific competition on growth, plant architecture, nitrogen accumulation, and yield of soybean as an effect of seven different plant densities and weather conditions. The study showed that intraspecific competition in soybean was conditioned by sowing density and access to water, thus revealing
\end{abstract}

Correspondence: Agnieszka Klimek-Kopyra, Department of Agroecology and Plant Production, University of Agriculture in Kraków, Aleja Mickiewicza 21, 31-120 Kraków, Poland.

E-mail: klimek.a@wp.pl

Key words: Plant competition; intraspecific relations; soybean; seed yield.

Received for publication: 23 July 2020.

Revision received: 30 September 2020.

Accepted for publication: 8 October 2020.

(C) Copyright: the Author(s), 2021

Licensee PAGEPress, Italy

Italian Journal of Agronomy 2021; 16:1709

doi:10.4081/ija.2020.1709

This article is distributed under the terms of the Creative Commons Attribution Noncommercial License (by-nc 4.0) which permits any noncommercial use, distribution, and reproduction in any medium, provided the original author(s) and source are credited. the true plant productive potential. Low intraspecific competition increased with plant density causing an increase in the yield of plants. In the wet year of 2014, strong intraspecific competition resulted in high yield and nitrogen accumulation only up to a density of 42 plants $\mathrm{m}^{-2}$, compared to dry years when nitrogen uptake of soybean increased with plant density in full range. The CI and ASC competition indices were sensitive to the varying amount of rainfall. Greater rainfall during crop vegetation increased the intensity of competition as well as the absolute severity of competition and decreased the relative yield with increasing density. In contrast, drought reduced intraspecific competition, eliminating it entirely at over 52 plants $\mathrm{m}^{-2}$.

\section{Introduction}

Soybean is the most important agricultural species of grain legumes (Annicchiarico, 2017). Its cultivation developed mainly in the Western Hemisphere, i.e. the United States, Brazil and Argentina. Due to the large amount of protein required to maintain large herds of farm animals (pigs, cattle, and poultry), soybean extraction meal (35 million tonnes), is imported to European countries (Visser et al., 2015; Zhang et al., 2017). About 14.9 million tonnes of soybean seeds are exported annually to EU countries, mainly to produce animal feed. The largest amounts of soybean are imported from the USA (60\%) and Brazil (32\%). Exports of this raw material from the USA amount to 50.9 million tonnes, i.e. about $41 \%$ of total production. The Netherlands $(28 \%)$ and Spain $(21 \%)$ are the largest soybean importers in the EU-28 (FAO, 2019). Observations of climate warming across Europe lead to increased interest in growing soybean. Because soybean is a relatively new species for Europe, there are still problematic management issues to be solved. One of them is the selection of sowing density, which, in combination with weather conditions, determines the productivity of plants (Rębilas et al., 2020). The selection of optimum plant density to obtain maximum yield in a given environment involves consideration of several interconnecting 
agrotechnical-environmental factors, including sowing pattern, cultivar maturity, nitrogen fixation and plant-plant competition. These factors have been studied in different species, including soybean, although with different depth (Vollmann, 2016; Annicchiarico, 2017). Luca and Hungria (2014) investigated the modulation of symbiotic nitrogen fixation in soybean at different plant densities and revealed that nitrogen fixation per plant was stimulated by low density. Neugschwandtner et al. (2020) highlighted that soybean is highly adaptable to different conditions through compensation processes during the formation of yield components. Consequently, from an agronomic point of view, cultivation of plants in a stressful dry environment with a low seeding rate and wider row spacing can be recommended. Contrasting findings were presented by Rębilas et al. (2020), who proved that high sowing density $\left(80 \mathrm{~m}^{-2}\right)$ can be recommended as optimal, since it provides a relatively high seed yield in water-scarce environments. Although the reported studies were related to the effect of plant densities on plant growth and seed yield, very few of them have considered aspects of intraspecific competition between plants as a driver of true productive plant potential. Competition exists between plants where independent demands for environmental factors exceed supply and usually plays a major role in generating the plant-to-plant variability in relative growth rates that affect frequency distributions of weight (Silvertown and Charlesworth, 2001).

Most research on soybean concerning the effects of competition has dealt with interspecific competition within weed-crop canopy (Nordby et al., 2007) or legume species and non-legume species mixtures (Caratti et al., 2016). The literature devoted little attention to the impact of the intraspecific competition occurring between plants of the same species on the productivity of soybean plants in different plant density.

The intensity of competition is defined as a reduction in plant performance caused by increasing plant density (Maddonni and Otegui, 2006). When plant density increases, the relative resource availability for individual plants decreases and population competitive intensity increases, resulting in decreases in plant biomass and seed yield per plant (Zhai et al., 2018). According to Weigelt and Jolliffe (2003), intensity of competition describes the variability of plant performance caused by competition relative to other environmental factors or sources of variation. Snaydon and Satorre (1989) and Snaydon (1991) used absolute severity of competition to describe the reduction in plant size relative to plant growth with very low plant population. The approach for the study of severity competition is to evaluate the intensity of competition from adjacent plants on the performance of target plants' (Weigelt and Jolliffe, 2003) biomass or plant size in plots with different plant densities. The assumption of this approach was studied only for maize cultivation (Zhai et al., 2018) providing a useful method for breeding high-yield maize varieties in the future. When considering improvement of soybean cultivation, undertaking similar research is advisable.

The aim of this study was to determine the impact of competitive intensity and severity of plant competition on the growth, plant architecture, nitrogen accumulation, and yield of soybean as an effect of different plant densities and years.

\section{Materials and methods}

\section{Study site}

The phenotypic data used in the model of intraspecific competition were obtained at the Experimental Station of the Agricultural University in Krakow in Prusy, Poland $\left(50^{\circ} 07^{\prime} 01^{\prime \prime} \mathrm{N}, 20^{\circ} 05^{\prime} 19^{\prime \prime} \mathrm{E}\right.$, $270 \mathrm{~m}$ above sea level). The experiment was carried out on degraded chernozem (Umbrisols). This type of soil is fine-grained, with moderate levels of $\mathrm{P}, \mathrm{K}$ and $\mathrm{Mg}, 1.21 \%$ organic carbon, and $0.16 \%$ total nitrogen.

\section{Experimental design}

A single-factor field experiment was set up in a randomised block design with three replications. The experimental factor was sowing density, with seven factor levels (20, 40, 60, 80, 100, 120, and 140 seeds $\mathrm{m}^{-2}$ ) using the soybean cultivar Augusta. The plant density did not correspond to the sowing density and was lower due to losses during germination and emergence stages (Table 1), although the seed germination was between 85 and $95 \%$ in the germination test conducted in laboratory conditions (ISTA, 2009). The harvested plot area was $10 \mathrm{~m}^{2}$. Cereals were the preceding crop for soybean in each year of the study. Before sowing, mineral fertilisers were applied, and the field was tilled with a harrow and a cultivator. Mineral fertilisation was applied as follows: initial dose of ammonium nitrate $(34 \%)$ at $40 \mathrm{~kg} \mathrm{~N} \mathrm{ha}^{-1}$, potash $(60 \%)$ at $120 \mathrm{~kg} \mathrm{~K}_{2} \mathrm{O} \mathrm{ha}^{-1}$, and triple granulated superphosphate (46\%) at 80 $\mathrm{kg} \mathrm{P}_{2} \mathrm{O}_{5}$ ha $^{-1}$. At flowering stage second dose of ammonium nitrate (34\%) was applied at $20 \mathrm{~kg} \mathrm{~N} \mathrm{ha}^{-1}$. Before sowing, seeds were inoculated by the commercial inoculant Nitragina (Bradyrhizobium japonicum). Sowing was carried out in April each year (25.04.2013, 25.04.2014 and 15.04.2015) using a seed drill at $20 \mathrm{~cm}$ row spacing. Plants were harvested in the first 10 days of September (06.09.2013, 10.09.2014 and 07.09.2015). Chemical protection of plants was applied during the growing period. Weed control was carried out twice. Basagran $480 \mathrm{SL}$ at the amount of $3 \mathrm{~L} \mathrm{ha}^{-1}$ and Fusilade Forte $150 \mathrm{Ec}$ at the amount of 0.5 $\mathrm{L} \mathrm{ha}^{-1}$ were applied. The fungicide Amistar 250 S.C. at the amount of $0.8 \mathrm{~L} \mathrm{ha}^{-1}$ was used to prevent fungal diseases.

\section{Morphological traits}

During the flowering stage, 10 plants were taken from each combination of density and from each replication to assess root dry matter (RDM). Image analysis was used to calculate the mean root diameter (MRD) and the root surface area (RSA). At full maturity, 40 plants were collected from each combination. Biometric measurements of the aerial parts were performed, and the following traits were determined: height to first node, number of shoots per

Table 1. Sowing densities and respective plant densities.

\begin{tabular}{|c|c|c|c|c|c|c|c|c|}
\hline \multicolumn{2}{|c|}{ Sowing density (seeds $\mathrm{m}^{-2}$ ) } & 20 & 40 & 60 & 80 & 100 & 120 & 140 \\
\hline \multirow[t]{4}{*}{ Plant density (plants $\mathrm{m}^{-2}$ ) } & 2013 & 10 & 20 & 32 & 39 & 47 & 54 & 55 \\
\hline & 2014 & 9 & 19 & 31 & 35 & 44 & 55 & 69 \\
\hline & 2015 & 14 & 26 & 37 & 52 & 69 & 77 & 83 \\
\hline & Mean & 11 & 21 & 33 & 42 & 53 & 62 & 69 \\
\hline
\end{tabular}


plant, number of nodes per plant, number of pods per plant, number of pods per shoot, and number of pods per node. Nitrogen content was determined in the plant material (seeds and straw) by the Kjeldahl method. The harvest index (HI) and nitrogen harvest index (NHI) were calculated.

\section{Weather data}

The mean temperature and total precipitation were obtained from an automatic weather station in Prusy, belonging to the Department of Crop Production, Agricultural University in Krakow. The measurements covered the period of soybean growth, i.e. April to September (Table 2).

\section{Statistical analysis}

The analysis of the mathematical models was performed by OriginPro 8.5 software. Statistical software Statistica version 13 was used to analyse the data by applying an analysis of variance (ANOVA) at a probability of $\mathrm{P}<0.05$, where significant differences among means were defined using the Tukey's test.

\section{Intraspecific competition of soybean as a function of its density}

\section{Density resulting in a constant final yield}

The dry biomass of soybean yield per unit area $(Y)$ and density $(N)$ were used to perform a linear regression analysis of $N / Y=1 / \mathrm{w}$ as a function of $N$ (Figure 1), where $w$ is the average weight per plant, and $1 / w$ is the reciprocal of per-plant biomass. The coefficients obtained were used to write Equation 1:

$$
Y=\frac{N}{b_{0}+b_{1} N}
$$

where $Y$ is the biomass in $\mathrm{g} \mathrm{m}^{-2}, N$ is the plant density in numbers $\mathrm{m}^{-2}$, and $b_{0}$ and $b_{1}$ are constants. Parameters $b_{0}$ and $b_{1}$ were estimated using Equation 2:

$$
\frac{1}{w}=\frac{N}{Y}=b_{0}+b_{1} N
$$

The slope $b_{1}$ provides information about the increase in $1 / w$ and thus the decrease in per-plant weight $w$ with each plant added to the population, and thus is the reciprocal of the maximum biomass per unit area achieved at infinite density $\left(b_{1}=1 / Y_{\max }\right)$. The intercept $b_{0}$ is the reciprocal of the virtual biomass of an isolated plant, and the ratio $b_{1} / b_{0}$ expresses the increase in $1 / w$ relative to its value without competition, and thus may be used as a measure of intraspecific competitive stress (Spitters, 1983).

\section{Relative yield}

To quantify the competitive effect of intraspecific competition, the relative yield $(R Y)$ was calculated using the following Equation 3:

$R Y=\frac{B Y_{h c}}{B Y_{l c}}$

where $B Y_{h c}$ and $B Y_{b c}$ are dry plant biomass yield under high competition and low competition, respectively. Density $w=1.5$ plant $\mathrm{m}^{-2}$ was considered a density without competition, while other plant densities represented higher competition (Spitters, 1983; Zhai et al., 2018). A relative yield index higher than 1 indicates that intraspecific competition increased dry biomass yield; an $R Y$ index lower than 1 indicates that competition reduced dry biomass yield; and an $R Y$ equal to 1 indicates no intraspecific competition.

The relative yield exponentially decreased when the plant density increased:

$R Y=a+b e^{-c N}$

where $\mathrm{N}$ is plant density in square metres.

The coefficient $a$ is the minimum relative yield achieved at infinite density:

$\lim _{N \rightarrow \infty} R Y=\lim _{N \rightarrow \infty}\left(a+b e^{-c N}\right)=a$

\section{Competitive intensity and absolute severity of aboveground competition}

Competitive intensity (CI) was calculated using Equation 5:

$C I=\left(\right.$ Size $_{l c}-$ Size $\left._{h c}\right) /$ Size $_{I c}$,

where Size $e_{l c}$ and Size $_{h c}$ are the plant size under low competition and under high competition, respectively. Shoot biomass yield was used as plant density of $1.5 \mathrm{pl} \mathrm{m}^{-2}$ was taken as low competition and other plant densities represented higher competition (Bonser, 2013; Zhai et al., 2018).

Absolute severity of competition (ASC) at a given density was calculated using Equation 6:

$A S C=\log _{10}\left(W_{l d} / W_{h c}\right)$,

\begin{tabular}{|c|c|c|c|c|c|c|c|c|}
\hline & & & mpera & ${ }^{3}\left({ }^{\circ} \mathrm{C}\right)$ & & & Rainft & mm) \\
\hline & 2013 & 2014 & 2015 & Average long-term & 2013 & 2014 & 2015 & Average long-term \\
\hline April & 8.8 & 11.3 & 9.1 & 8.7 & 20.1 & 43.0 & 19.4 & 33.0 \\
\hline May & 14.2 & 14.3 & 13.3 & 14.0 & 98.8 & 107.5 & 101.6 & 58.0 \\
\hline June & 17.6 & 16.7 & 17.5 & 16.8 & 213.1 & 80.1 & 52.6 & 76.0 \\
\hline July & 19.2 & 20.4 & 20.6 & 18.1 & 27.2 & 183.2 & 71.8 & 74.9 \\
\hline Aug & 18.8 & 17.7 & 22.0 & 17.9 & 25.7 & 142 & 41.8 & 78.5 \\
\hline Sep & 12.0 & 15.2 & 15.2 & 12.3 & 86.1 & 98.2 & 69.4 & 65.4 \\
\hline
\end{tabular}

Table 2. Mean temperature and total precipitation during the years of the study. 
where $W_{l c}$ is the size of plants grown without neighbours (under low competition), and $W_{h c}$ is the size of plants grown with neighbours (at a given density). The population density $1.5 \mathrm{pl} \mathrm{m}^{-2}$ was assumed to be the no-competition conditions (Snaydon and Satorre, 1989; Snaydon, 1991).

\section{Results}

\section{Weather conditions}

Weather conditions varied in the years of the study (Table 2). In 2013, May and June were relatively wet with respect to the requirements of soybean. The year 2014 was the wettest of the three years of the study, due to heavy rains in May and July, when the respective total precipitation was 107 and $183 \mathrm{~mm}$. In the next year (2015), May was very wet, but the recorded total precipitation of the growing season $(357 \mathrm{~mm})$ was lower than in $2013(471 \mathrm{~mm})$ and $2014(654 \mathrm{~mm})$.

\section{A}

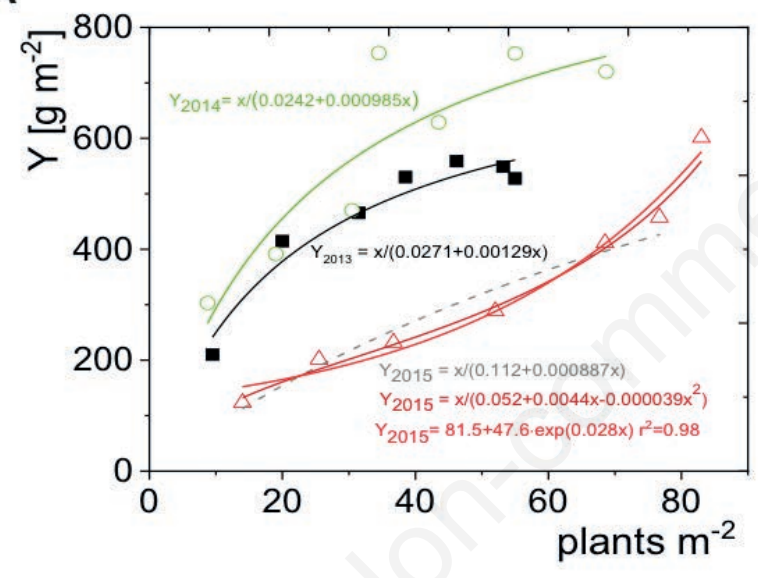

B

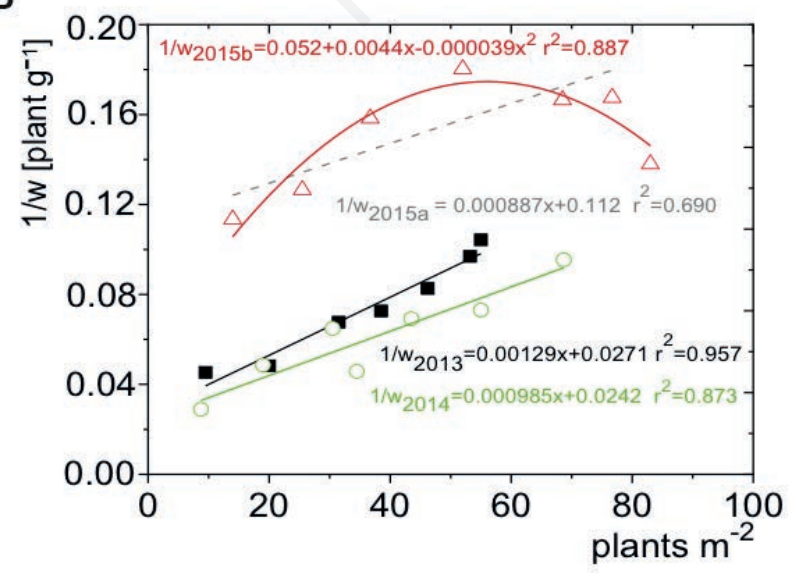

Figure 1. Effect of soybean density on dry biomass yield $(Y)$ per area (A); effect of soybean density on the reciprocal $(1 / w)$ of dry biomass yield per plant (B).
Intraspecific competition of soybean as a function of its density

\section{Density resulting in a constant final yield}

Using the coefficients from the linear regression, the theoretical maximum yield of dry weight per unit area $\left(Y_{\max }\right)$ achieved at infinite density was $1 / b_{1(2013)}=775.2 \mathrm{~g} \mathrm{~m}^{-2}, 1 / b_{1(2014)}=1015.23 \mathrm{~g} \mathrm{~m}^{-2}$, and $1 / b_{1(2015)}=1127.4 \mathrm{~g} \mathrm{~m}^{-2}$, for crops harvested in the years 2013 , 2014 and 2015, respectively. For each soybean plant added to the population (Figure 1), the reciprocal of the dry biomass per plant $(1 / w)$ increased, or the dry biomass per plant $(w)$ was reduced by $b_{1(2013)}=0.00129 \mathrm{~g}, b_{1(2014)}=0.000985 \mathrm{~g}$, and $b_{1(2015)}=0.000887 \mathrm{~g}$.
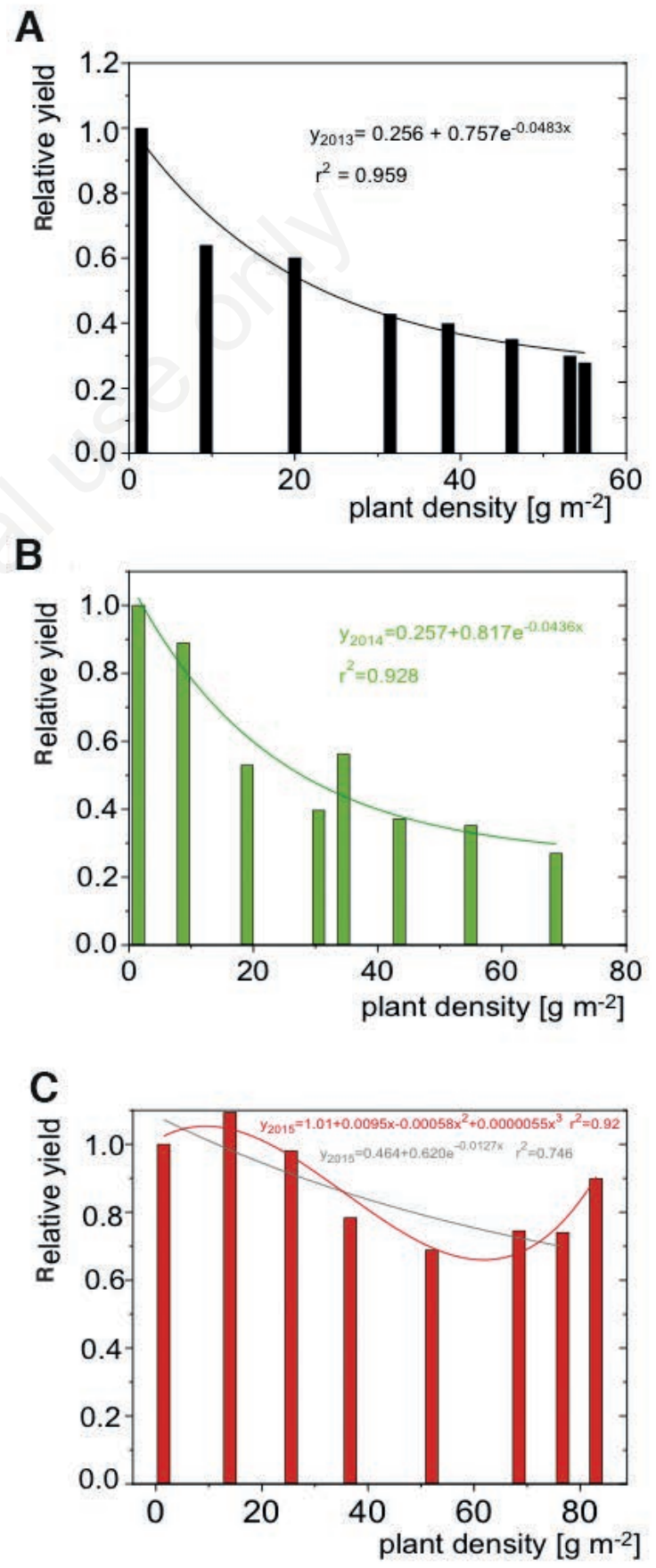

Figure 2. Response of relative yield to increased plant density in the years of the study (A) 2013, (B) 2014 and (C) 2015. 
Biomass yield increased with plant density as a result of maximised intraspecific competition.

The reduction in biomass yield per plant when an additional plant was added to the population was lowest for soybeans harvested in 2013 and highest in 2015.

The ratio $b_{1} / b_{0}$ expressing the increase in $1 / w$ relative to its value without competition may be used as a measure of intraspecific competition. This ratio was equal to $b_{1} / b_{0(2013)}=0.0476$; $b_{1} / b_{0(2014)}=0.0407$ and $b_{1} / b_{0(2015)}=0.008$, suggesting that the lowest competition took place in 2015. This significantly lower level of competition was probably related to the drought that year. A strong level of competition (about five times stronger) was noted in 2014, and the strongest competition occurred in 2013.

\section{Relative yield}

The estimated $R Y$ values were lower than at a non-competing density of 1.5 plants $\mathrm{m}^{-2}$, which indicates that the increased plant density reduced dry biomass yield. One exception occurred in 2015 , when the plant density of 15 plants $\mathrm{m}^{-2}$ had a $R Y$ higher than 1 (Figure 2C). The smallest $R Y$ value hypothetically achieved at infinity was obtained for soybean plants harvested in 2013 $(a=0.256)$ (Figure 2A), followed by $2014(a=0.257)$ (Figure 2B). The highest $R Y$ value was obtained in the drought year 2015 $(a=0.464)$. Low intraspecific competition between plants in 2015 was due to the smaller weight of individual plants in that year. Competition was higher in 2013 and 2014 compared to 2015.

The analysis of the residuals between the reciprocal of perplant biomass $(1 / w)$ values calculated by the model and those from experimental data was performed using the Shapiro-Wilk test with $95 \%$ confidence, for an average equal to zero. This test analyses a statistical sample and checks if the population that was taken from has a normal distribution around its average value (Shapiro and Wilk, 1965; Nicolin et al., 2015). The results of the analysis as well as the mean squared errors (MSE) are presented in Table 3.

The probability values calculated using the Shapiro-Wilk test were greater than $0.05(\mathrm{P} \geq 0.05)$, which shows that the tested residuals were part of a normal distribution. An analysis of mean squared errors was performed.

Due to drought in 2015, the linear model did not fit the data satisfactorily. The reciprocal of per-plant biomass $(1 / w)$ increased with increasing density up to values of 50-60 plants $\mathrm{m}^{-2}$ and then decreased. Intra-species competition varies with plant density compared to other years.

For the data from 2015, the parabolic model better describes the experimental data, which is confirmed by higher $r^{2}$ value for the parabolic model $\left(r^{2}=0.89\right)$ than $r^{2}$ value for the linear model $\left(r^{2}=0.69\right)$. Additionally, lower mean squared error was obtained for the parabolic model $\left(\mathrm{MSE} 10^{3}=3.11\right)$ compared to the linear model $\left(\mathrm{MSE} 10^{3}=5.95\right)$.

The curves shown in Figure 1A were performed using param- eters calculated from the data in Figure 1B (Equations 1 and 2).

Dependence of relative yield as a function of plant density (Figure 2) was described well with the exponential model for the data registered in $2013\left(r^{2}=0.96\right)$ and in $2014\left(r^{2}=0.93\right)$. For the data collected in 2015 the cubic model $\left(r^{2}=0.92\right)$, was better compared to the exponential model $\left(r^{2}=0.75\right)$. The cubic model also had a better $\mathrm{P}$-value $(\mathrm{P}=0.88)$ with a lower mean squared error $\left(\mathrm{MSE} 10^{3=} 14.8\right)$ compared to the exponential model with $\mathrm{P}=0.42$ and $\mathrm{MSE} 10^{3}=30.3$.

\section{Competitive intensity and absolute severity of aboveground competition}

The $C I$ and $A S C$ coefficients of the soybean crops increased

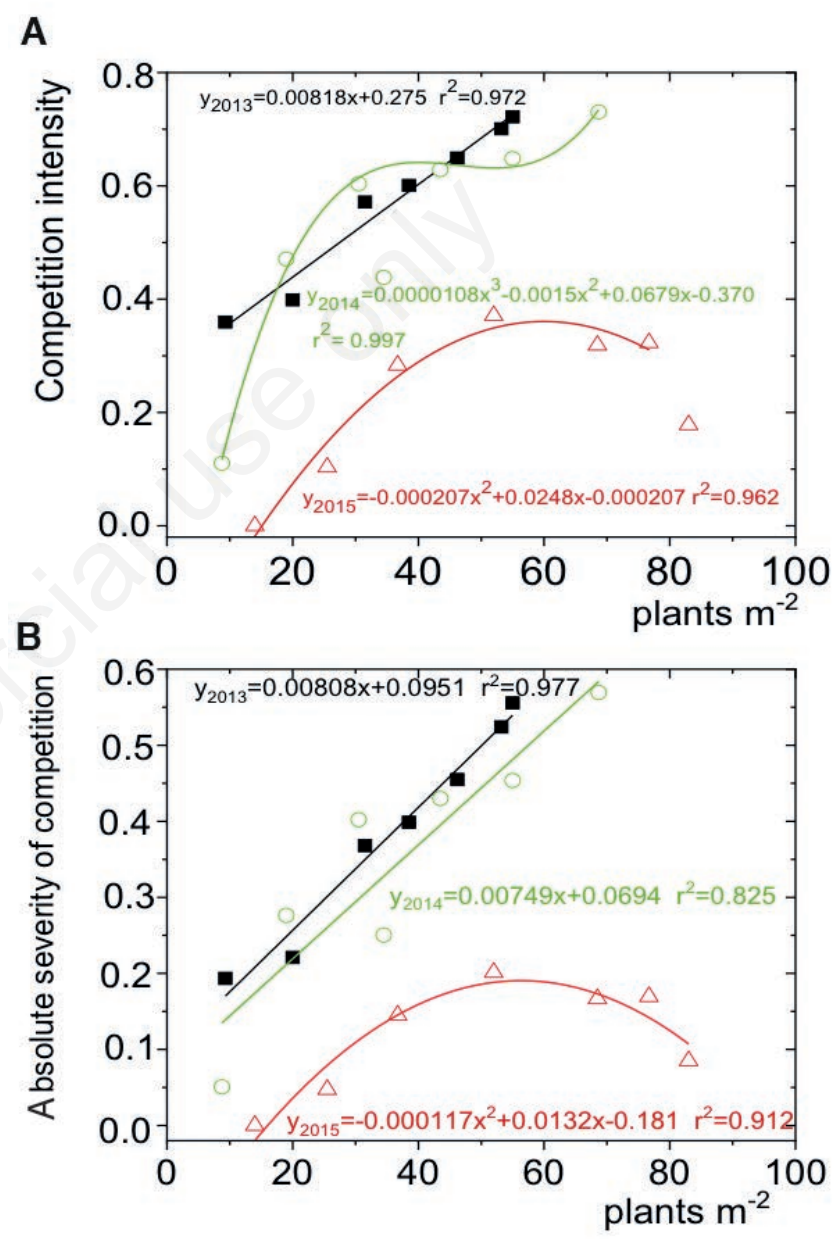

Figure 3. Response of competition intensity (CI) (A) and absolute severity of competition (ASC) (B) to plant density.

Table 3. Probability values for Shapiro-Wilk (95\%) test and MSE for dependencies $1 / w(\mathrm{~N})$ and $\mathrm{RY}(\mathrm{N})$ where $1 / w$ is the reciprocal of per-plant biomass; $N$ is the plant density in numbers $\mathrm{m}^{-2} ; R Y$ is the relative yield $\left(R Y=\frac{B Y_{h c}}{B Y_{l c}}, B Y_{b c}\right.$ and $B Y_{b c}$ are dry plant biomass yield
under high competition and low competition).

\begin{tabular}{|c|c|c|c|c|}
\hline \multirow[t]{2}{*}{ Year } & \multicolumn{2}{|c|}{$1 / w(N)$} & \multicolumn{2}{|c|}{$R Y(N)$} \\
\hline & P-value (95\%) & MSE $\times 10^{3}$ & P-value (95\%) & MSE $\times 10^{3}$ \\
\hline 2013 & 0.851 & 1.76 & 0.467 & 17.2 \\
\hline 2014 & 0.937 & 2.93 & 0.617 & 25.2 \\
\hline $2015 \mathrm{a}$ & 0.0764 & 5.95 & 0.415 & 30.3 \\
\hline $2015 b$ & 0.507 & 3.11 & 0.878 & 14.8 \\
\hline
\end{tabular}


with plant density (Figure 3 ). The relationship between competitive intensity and plant density was linear for the data recorded in 2013 (Figure 3A), whereas for the measurements recorded in 2014 and 2015 it was described by cubic and quadratic functions, respectively. In optimal weather conditions (year 2013) the intensity of plant competition was very high and already appeared at low density which was not present in other years. This means that plant competition for natural resources increases with density even in optimal environmental conditions. The data obtained in 2015 deviated from the other years, which was due to drought. In that year the maximum competition was noted at the plant density of 53 plants $\mathrm{m}^{-2}$, and plant competition was not affected by the highest plant density. However, in a wet year (2014) we observed two maxima of intensity of competition, at low and high density (40 and 70 plants $\mathrm{m}^{-2}$ respectively), which was related with different access to water for plants during the season. When plant density increases, a higher value of the $C I$ coefficient is observed, which is related to the lower availability of water for individual plants and causes reduction of the plant biomass as well as seed yield per plant. The relationship between the absolute severity of competition and plant density was linear for the data recorded in 2013 and 2014 (Figure 3B). A higher slope was observed in 2013, suggesting a higher level of competition between plants in that year, which is in agreement with the results obtained using other methods.

In 2015 , the data were better described by a square function with the maximum of the absolute severity index for plant density equal to 52 plants $\mathrm{m}^{-2}$. As already stated, the absolute severity of competition describes the reduction in plant size relative to plant growth with very low plant population, which was noticed mainly during the drought that appeared in 2015. In that year a biomass and seed yield reduction were observed. In the optimal and wet years, reduction of plant size relative to plant growth was not observed.

\section{Nitrogen accumulation in yield and nitrogen harvest index val- ues as an effect of aboveground plant competition}

Figure 4A shows an increase in nitrogen accumulation in the seed yield as a function of plant density in the canopy. The increase was smallest in $2015\left(a=23.05\left[\mathrm{~kg} \mathrm{ha}^{-1} /\right.\right.$ plant $\left.\left.^{-2}\right]\right)$, intermediate in $2014\left(a=34.5\left[\mathrm{~kg} \mathrm{ha}^{-1} / \mathrm{plant} \mathrm{m}^{-2}\right]\right)$, and largest in $2013(a=39.5[\mathrm{~kg}$ $\mathrm{ha}^{-1} /$ plant $\left.\mathrm{m}^{-2}\right]$ ). Nitrogen accumulation was strongly related to environmental conditions and plant intensity competition. The observed drought in 2015 resulted in lower nitrogen accumulation in biomass, compared to optimal weather conditions recorded in 2013. Water shortage resulted in limiting the plants to actively exploring the soil for water and nutrient resources.

The highest seed yields were obtained in 2013 and 2014, when there was more rainfall.
The highest values for the nitrogen harvest index (Figure 4B) were obtained in the wet years (2013 and 2014), and the lowest values were obtained in the dry year (2015). At the same time, the decrease in NHI values with increased plant density was slightly more accentuated in 2014 than in the two other years.

Analysis of the residuals between the seed yield values and the NHI values calculated by the model and those from experimental data was performed using the Shapiro-Wilk test with 95\% confidence, for an average equal to zero. All the results are presented in
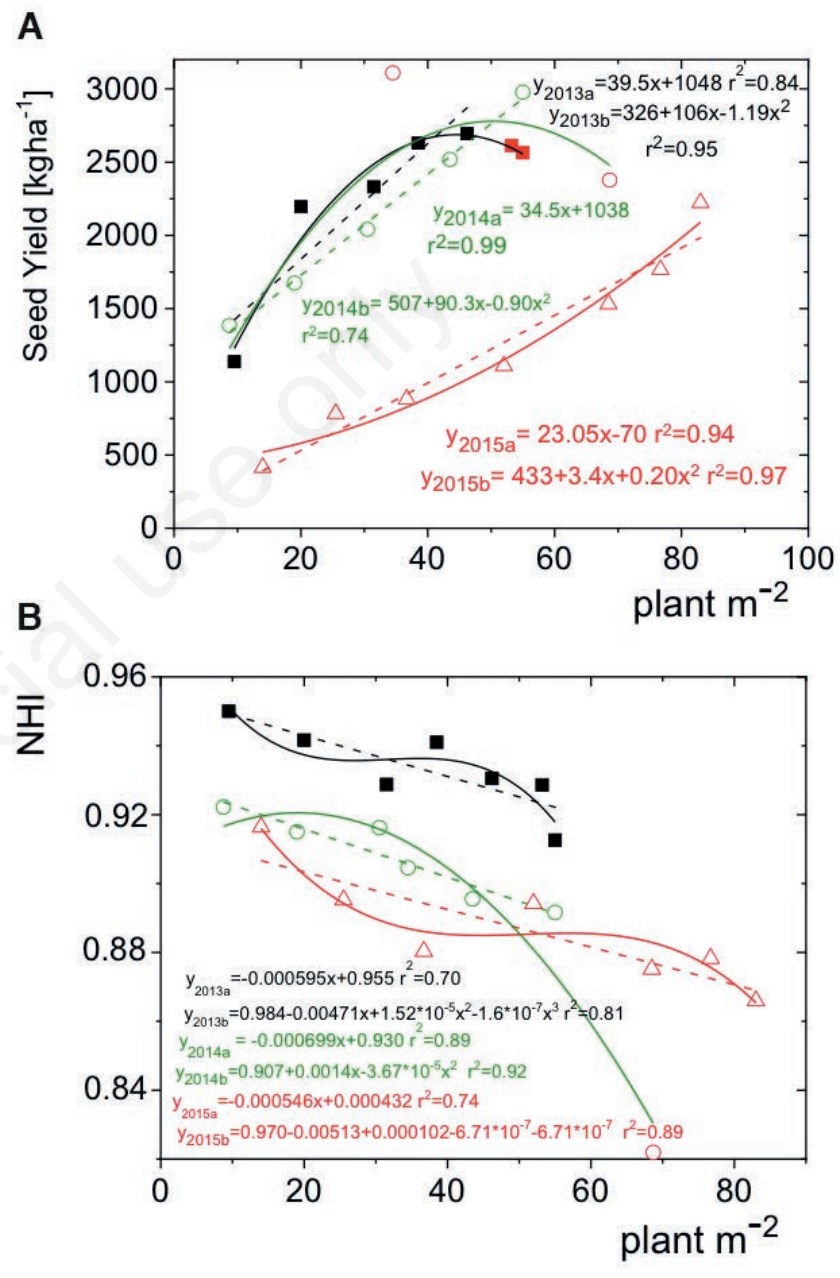

Figure 4. Seed yield (A) and nitrogen harvest index (NHI) (B) depending on plant sowing density.

Table 4. Probability values for Shapiro-Wilk (95\%) test and MSE for dependencies SY(N) and NHI(N), where SY is the nitrogen uptake of seed yield, NHI is nitrogen harvest index, and $\mathrm{N}$ is plant density in numbers $\mathbf{~ m}^{-2}$.

\begin{tabular}{lcccc} 
Year & P-value $(95 \%)$ & SY(N) & P-value $(95 \%)$ & NHI(N) \\
& 0.780 & 111 & 0.844 & 2.53 \\
$2013 a^{*}$ & 0.288 & 44.4 & 0.516 & 2.01 \\
$2013 \mathrm{~b}$ & 0.247 & 18.7 & $0.791^{*}$ & 1.64 \\
\hline $2014 \mathrm{a}^{*}$ & 0.619 & 123 & 0.156 & 3.56 \\
$2014 \mathrm{~b}$ & 0.683 & 53.3 & 0.601 & 3.21 \\
\hline $2015 \mathrm{a}^{*}$ & 0.113 & 39.8 & 0.586 & 2.08 \\
$2015 \mathrm{~b}$ & & MSEx & \\
\hline
\end{tabular}

*The points marked in the graph were not included in the analysis. 
Table 4. Statistical analysis was performed for linear as well as a polynomial model, applied to the SY(N) and NHI(N) dependencies.

The probability values calculated using the Shapiro-Wilk test for both tested models were greater than 0.05 ( $\mathrm{P} \geq 0.05$ ), confirming that the tested residuals were part of a normal distribution. For linear fitting, the most divergent data points were omitted. For most of the fits, slightly higher values of $r^{2}$ as well as smaller MSE values were obtained for the polynomial model, suggesting that this model slightly better describes the experimental data.

\section{Total root biomass as a function of plant density}

The experimental data on soybean root biomass as a function of plant density in the years 2013, 2014 and 2015, as well as the results for the respective fits of the curve given by equation to the data are shown in Figure 5. Each point on the graph represents the average root weight obtained from four plants.

The root biomass increased with plant density, according to the parabolic function shown in Figure 5. The largest root biomass at zero (low competition) density was registered in $2015\left(y_{2015}=25.3\right.$ $\left.\mathrm{g} \mathrm{m}^{-2}\right)$, followed by $2013\left(y_{2013}=22.7 \mathrm{~g} \mathrm{~m}^{-2}\right)$ and $2014\left(y_{2014}=11.8\right.$ $g^{-2}$ ). The increase in root biomass was slightly higher in 2015 compared to the other years, as a result of individual plant response to water shortage (Figure 5).

\section{Aboveground plant productivity in relation to plant density}

The recorded biometric features varied among years and under the influence of plant density (Table 5). The amount of water was the factor that most strongly influenced the morphotype of plants in the canopy. All features differed significantly among years. The number of shoots per plant, which is the most important feature, was high in the years with more rainfall. The low rainfall in 2015 resulted not only in a reduction in the number of shoots on the plant, but also the number of nodes per plant, number of pods per shoot, number of pods per nodes and, consequently, the yield and HI. The morphotype of soybean plants varied depending on the crop density, but only with respect to certain features. The density had a significant impact on the height of the first pod-setting node, the number of shoots per plant, the number of nodes per plant, the

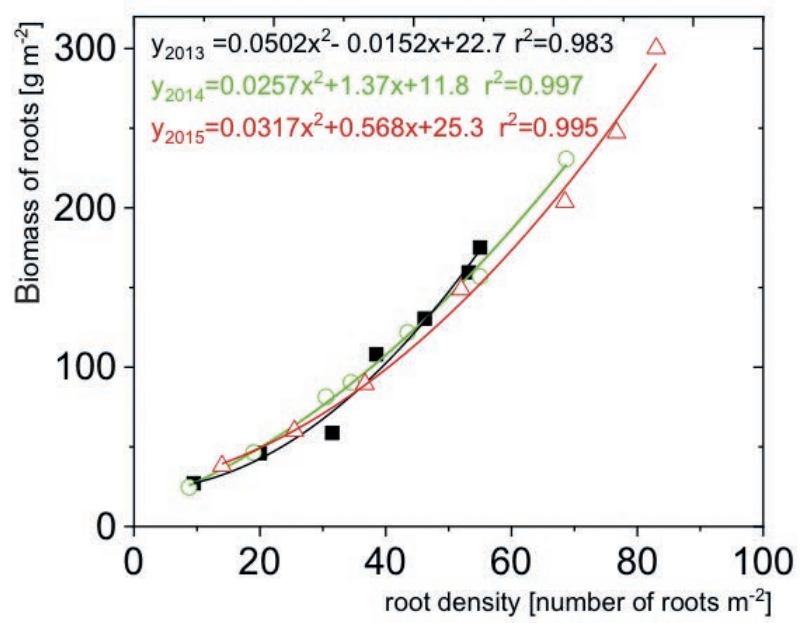

Figure 5. Biomass of soybean roots as a function of plant density.

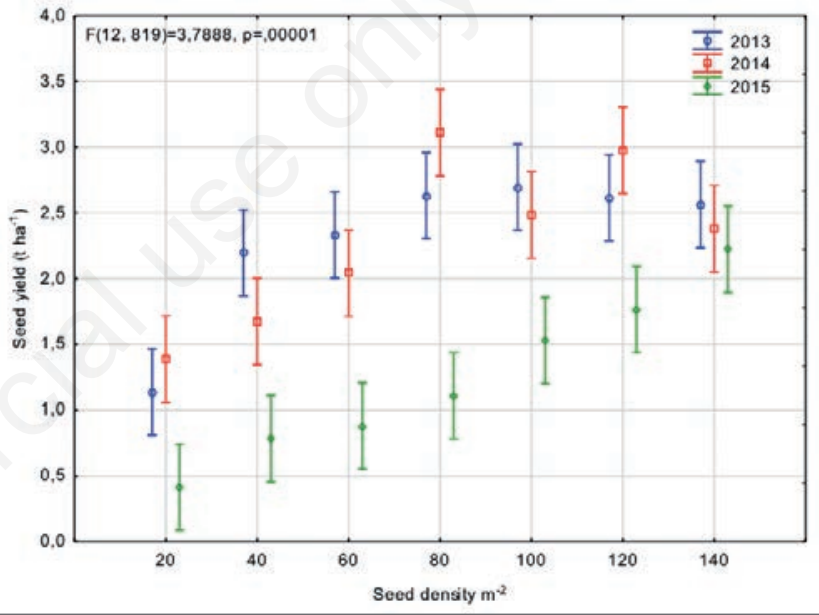

Figure 6. Effect of the interaction of the experimental factors (year $\times$ plant density) on seed yield.

Table 5. Seed yield and selected biometric parameters of soybean plants in relation to the experimental factors (year and plant density).

\begin{tabular}{|c|c|c|c|c|c|c|c|c|}
\hline Factor & $\begin{array}{c}\text { Seed } \\
\text { yield } \\
\left(\mathrm{kg} \mathrm{ha}^{-1}\right)\end{array}$ & $\begin{array}{l}\text { Height to } \\
\text { first node } \\
\text { (cm) }\end{array}$ & $\begin{array}{c}\text { Number of } \\
\text { shoots } \\
\text { per plant }\end{array}$ & $\begin{array}{c}\text { Number of } \\
\text { nodes } \\
\text { per plant }\end{array}$ & $\begin{array}{l}\text { Number of } \\
\text { pods per } \\
\text { plant (pcs) }\end{array}$ & $\begin{array}{l}\text { Number of } \\
\text { pods per } \\
\text { shoot }\end{array}$ & $\begin{array}{c}\text { Number of } \\
\text { pods per } \\
\text { node }\end{array}$ & HI \\
\hline \multicolumn{9}{|c|}{ Year (Y) } \\
\hline 2013 & $2321.4^{\mathrm{a}}$ & $9.73^{\mathrm{c}}$ & $2.23^{b}$ & $13.3^{b}$ & $26.5^{b}$ & $13.3^{\mathrm{a}}$ & $1.99^{\mathrm{a}}$ & $0.50^{\mathrm{a}}$ \\
\hline 2014 & $2292.4^{\mathrm{a}}$ & $13.5^{b}$ & $3.58^{\mathrm{a}}$ & $21.2^{\mathrm{a}}$ & $36.9^{\mathrm{a}}$ & $9.98^{b}$ & $1.64^{\mathrm{b}}$ & $0.39^{\mathrm{b}}$ \\
\hline 2015 & $1247.1^{\mathrm{b}}$ & $17.9^{\mathrm{a}}$ & $1.62^{c}$ & $9.14^{c}$ & $14.0^{c}$ & $9.96^{\mathrm{b}}$ & $1.50^{c}$ & $0.37^{c}$ \\
\hline $\mathrm{P}$ & $<0.0001$ & $<0.0001$ & $<0.0001$ & $<0.0001$ & $<0.0001$ & $<0.0001$ & $<0.0001$ & $<0.0001$ \\
\hline \multicolumn{9}{|c|}{ Plant density (PD) $\mathrm{m}^{-2}$} \\
\hline 11 & $979.2^{\mathrm{c}}$ & $9.38^{\mathrm{c}}$ & $3.59^{\mathrm{a}}$ & $22.4^{\mathrm{a}}$ & 43.3 & 11.9 & $1.86^{\mathrm{a}}$ & $0.46^{\mathrm{a}}$ \\
\hline 21 & $1551.2^{\mathrm{b}}$ & $12.1^{\mathrm{b}}$ & $3.15^{\mathrm{a}}$ & $17.7^{\mathrm{b}}$ & 31.7 & 10.6 & $1.77^{\mathrm{b}}$ & $0.44^{\mathrm{ab}}$ \\
\hline 33 & $1751.4^{b}$ & $13.0^{\mathrm{b}}$ & $2.54^{\mathrm{b}}$ & $14.2^{c}$ & 24.6 & 10.9 & $1.73^{b}$ & $0.43^{\text {bd }}$ \\
\hline 42 & $2307.4^{\mathrm{a}}$ & $14.6^{\mathrm{a}}$ & $2.50^{\mathrm{bc}}$ & $15.0^{\mathrm{b}}$ & 27.1 & 11.5 & $1.74^{\mathrm{b}}$ & $0.43^{\mathrm{bd}}$ \\
\hline 53 & $2236.4^{\mathrm{a}}$ & $14.4^{\mathrm{a}}$ & $2.05^{\mathrm{cd}}$ & $11.8^{\mathrm{d}}$ & 20.5 & 4.72 & $1.72^{\mathrm{c}}$ & $0.41^{\text {cd }}$ \\
\hline 62 & $2451.9^{\mathrm{a}}$ & $15.5^{\mathrm{a}}$ & $1.75^{\mathrm{d}}$ & $10.7^{\mathrm{d}}$ & 18.1 & 4.80 & $1.66^{\mathrm{c}}$ & $0.41^{\mathrm{cd}}$ \\
\hline 69 & $2387.5^{\mathrm{a}}$ & $16.8^{\mathrm{a}}$ & $1.77^{\mathrm{d}}$ & $10.1^{\mathrm{d}}$ & 15.1 & 5.59 & $1.50^{c}$ & $0.38^{c}$ \\
\hline $\mathrm{P}$ & $<0.0001$ & $<0.0001$ & $<0.0001$ & $<0.0001$ & ns & ns & $<0.0001$ & $<0.0001$ \\
\hline$Y \times P D$ & $<0.0001$ & $<0.0001$ & $<0.0001$ & $<0.0001$ & $<0.0001$ & $<0.0001$ & $<0.0001$ & $<0.0001$ \\
\hline
\end{tabular}

$\mathrm{HI}$, harvest index. Different letters indicate significant difference at $\mathrm{P}<0.05$ by Tukey's test. 
number of pods per node and HI. The density had little effect on the number of pods per plant and per shoot. The number of pods developed from each node was found to depend on the density. As the density of the canopy increases, the number of pods decreases. The characteristically high number of shoots per plant with low plant density did not translate into an increase in plant yield.

The seed yield depended on the amount of rainfall, followed by the plant density (Figure 6). In the dry year, no variation in yield was shown at a low plant density of $11-33 \mathrm{~m}^{-2}$. As the density increased to more than 33 plants, the yield increased systematically. In the wet year, optimum yields were noted at a density of 42 plants $\mathrm{m}^{-2}$; no increase in crop yield was observed above this density.

\section{Nitrogen accumulation in the seeds and straw and nitrogen harvest index in relation to seed density}

Accumulation of nitrogen in the seed yield and the NHI were significantly dependent on weather conditions (Table 6). Excess rainfall in 2014 contributed to increased nitrogen accumulation in both the seeds and the straw. Analysis of nitrogen accumulation in the seeds showed a linear trend of $\mathrm{N}$ accumulation as the plant density increased, which persisted up to the medium-level plant density of 42 plants $\mathrm{m}^{-2}$. The maximum accumulation of $\mathrm{N}$ in the seeds was noted at high plant density.

Nitrogen uptake with seed yield is the result of two factors, that is, water availability and plant density, which is confirmed by the significant interaction of these two factors (Figure 7A). In the wet year, plants took up most nitrogen with the seed yield $\left(190 \mathrm{~kg} \mathrm{ha}^{-1}\right)$

Table 6. Nitrogen uptake $\left(\mathrm{kg} \mathrm{ha}^{-1}\right)$ in seed and straw, and nitrogen harvest index in relation to the year and plant density.

\begin{tabular}{|c|c|c|c|}
\hline Factor & N uptake straw $\left(\mathrm{kg} \mathrm{t}^{-1}\right)$ & N uptake seed $\left(\mathrm{kg} \mathrm{t}^{-1}\right)$ & NHI \\
\hline \multicolumn{4}{|c|}{ Year (Y) } \\
\hline 2013 & $3.47^{\mathrm{c}}$ & $139.8^{\mathrm{a}}$ & $0.93^{\mathrm{a}}$ \\
\hline 2014 & $7.55^{\mathrm{a}}$ & $140.2^{\mathrm{a}}$ & $0.89^{b}$ \\
\hline 2015 & $4.32^{\mathrm{b}}$ & $70.8^{b}$ & $0.88^{b}$ \\
\hline $\mathrm{P}$ & $<0.0001$ & $<0.0001$ & $<0.0001$ \\
\hline \multicolumn{4}{|c|}{ Plant density (PD) $\mathrm{m}^{-2}$} \\
\hline 11 & $1.39 \mathrm{e}$ & $57.3^{\mathrm{c}}$ & $0.92^{\mathrm{a}}$ \\
\hline 21 & $2.64^{\mathrm{d}}$ & $89.7^{\mathrm{b}}$ & $0.91^{\mathrm{ab}}$ \\
\hline 33 & $3.43^{\mathrm{d}}$ & $105.2^{b}$ & $0.91^{\mathrm{ab}}$ \\
\hline 42 & $5.31^{\mathrm{c}}$ & $140.1^{\mathrm{a}}$ & $0.90^{\mathrm{b}}$ \\
\hline 53 & $6.12^{c}$ & $135.8^{\mathrm{a}}$ & $0.90^{\mathrm{b}}$ \\
\hline 62 & $7.35^{\mathrm{b}}$ & $147.7^{\mathrm{a}}$ & $0.89^{b}$ \\
\hline 69 & $9.56^{\mathrm{a}}$ & $142.7^{\mathrm{a}}$ & $0.87^{\mathrm{c}}$ \\
\hline $\mathrm{P}$ & $<0.0001$ & $<0.0001$ & $<0.0001$ \\
\hline
\end{tabular}

NHI, nitrogen harvest index. Different letters indicate significant difference at $\mathrm{P}<0.05$ by Tukey's test.

Table 7. Selected morphological parameters of soybean roots in relation to the experimental factors (year and plant density).

\begin{tabular}{|c|c|c|c|}
\hline Factor & RDM $\left(\mathrm{g} \mathrm{cm}^{-3}\right)$ & $\operatorname{RSA}\left(\mathrm{cm}^{2} \mathrm{~cm}^{-3}\right)$ & MRD (mm) \\
\hline \multicolumn{4}{|c|}{ Year (Y) } \\
\hline 2013 & 0.0046 & $2.61^{\mathrm{a}}$ & $0.64^{\mathrm{a}}$ \\
\hline 2014 & 0.0049 & $0.99 c$ & $0.55^{\mathrm{b}}$ \\
\hline 2015 & 0.0050 & $2.15^{\mathrm{b}}$ & $0.66^{\mathrm{a}}$ \\
\hline $\mathrm{P}$ & ns & $<0.0001$ & $<0.01$ \\
\hline \multicolumn{4}{|c|}{ Plant density (PD) $\mathrm{m}^{-2}$} \\
\hline 11 & 0.0049 & 1.92 & 0.57 \\
\hline 21 & 0.0041 & 1.37 & 0.64 \\
\hline 33 & 0.0040 & 1.48 & 0.67 \\
\hline 42 & 0.0048 & 2.37 & 0.61 \\
\hline 53 & 0.0050 & 1.79 & 0.62 \\
\hline 62 & 0.0052 & 2.15 & 0.61 \\
\hline 69 & 0.0059 & 2.35 & 0.60 \\
\hline p & ns & ns & ns \\
\hline $\mathrm{Y} \times \mathrm{PD}$ & ns & ns & ns \\
\hline
\end{tabular}

RDM, root dry matter; RSA, root surface area; MRD, mean root diameter. Different letters indicate significant difference at $\mathrm{P}<0.05$ by Tukey's test. 
at the medium-level canopy density of 42 plants $\mathrm{m}^{-2}$. A similar trend was observed in the year with favourable rainfall distribution (2013). In the dry year (2015), nitrogen uptake increased with plant density in the canopy. Plants took up most nitrogen with the seed yield $\left(147 \mathrm{~kg} \mathrm{ha}^{-1}\right)$ at a density of 62 plants $\mathrm{m}^{-2}$ and the least (about $57 \mathrm{~kg} \mathrm{ha}^{-1}$ ) at the lowest density. This indicates that in the event of drought stress, plants should be sown at a higher density.

The nitrogen harvest index was inversely proportional to the plant density (Figure 4B). As the density increased, the NHI value decreased.

\section{Root productivity in relation to seed density}

Soybean root weight showed little variation depending on the year and canopy density (Table 7). A slight increase in RDM was noted as a result of increased plant density above 42 plants $\mathrm{m}^{-2}$ (not significant). However, this did not translate into RSA or MRD. The root parameters RSA and MRD were significantly dependent on the amount of rainfall in the test years. In the dry year (2015), the surface area of the roots and their diameter increased significantly compared to the wet year. The results proved that the root surface and root diameter were only affected by environmental
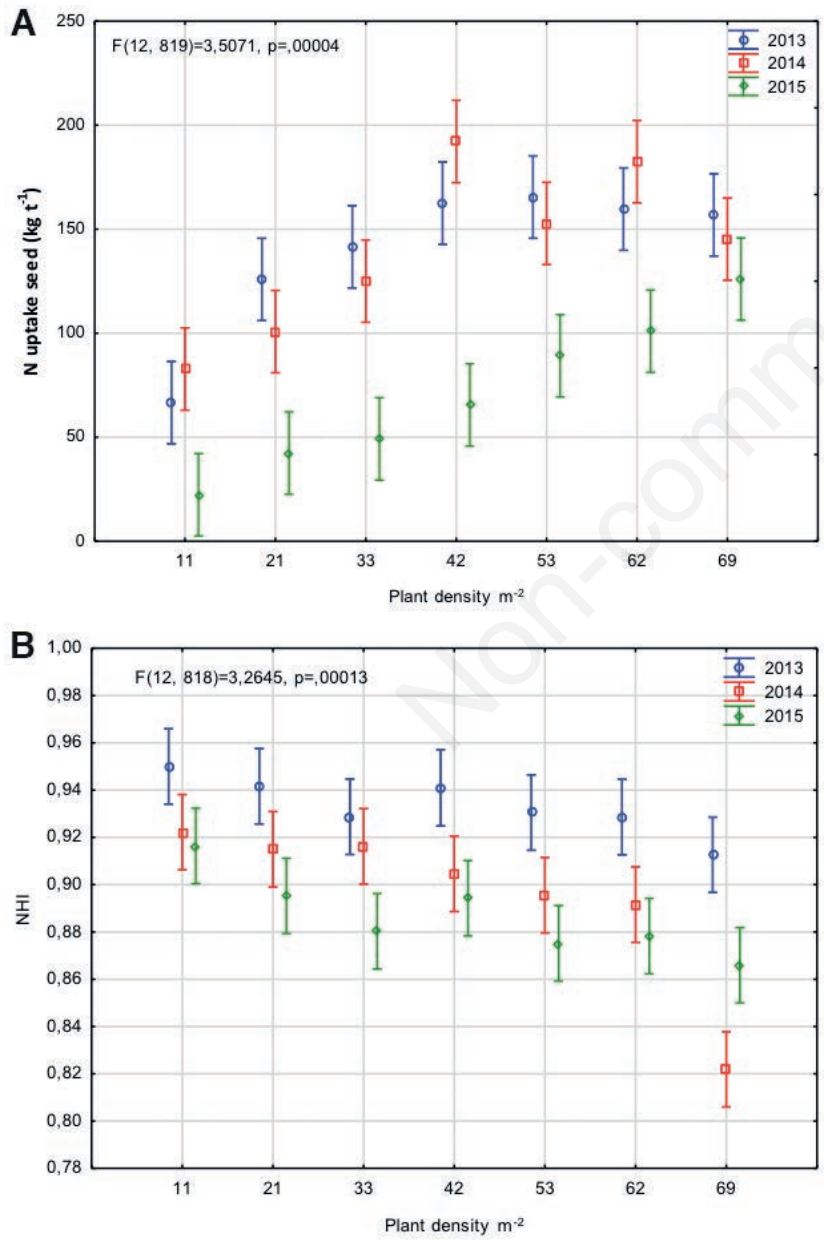

Figure 7. Effect of the interaction of the experimental factors (year $\times$ plant density) on $\mathrm{N}$ uptake seed $\left(\mathrm{kg} \mathrm{t}^{-1}\right)(\mathrm{A})$ and nitrogen harvest index (NHI) (B). conditions. Root diversity as characterised by root diameter, root surface area and root biomass, was not changed by plant density, which indicates that plants did not suffer resource or water depletions and did not compete intensively.

\section{Discussion}

Intraspecific competition is conditioned by the density of plants in the canopy and affects the amount of accumulated biomass, both aboveground and belowground (Maddonni and Otegui, 2006; Werner et al., 2016; Yang et al., 2019). As plant density in the canopy increases, plants increase competition for habitat resources by producing more biomass, which can have a negative impact on seed yield (Wang et al., 2005; Klimek-Kopyra et al., 2017). The level of density is important in intraspecific competition because it presents curvilinear relationships indicating the optimum density for plants (Assefa et al., 2016; Qian et al., 2016). For this reason, the established sowing rate standards have been thought not to be subject to adjustment. However, known ecological laws and sowing standards established on their basis do not take into account changes in weather observed in recent years, i.e. anomalies in the amount and distribution of rainfall. One of the oldest studies on the yield potential of crop plants, including soybean, conducted by Donald (1981), showed that plants with high yield potential have lower potential for intraspecific competition, indicating greater uniformity in the crop even in stress conditions. Recent research on crop yield potential (Board and Kahlon, 2013; Luca and Hungria, 2014; Klimek-Kopyra et al., 2017) has supported that theory, indicating that soybean exhibits high phenotypic plasticity, including the capacity to modify its growth and yield components depending on the number of individuals on the surface, thus maintaining consistent yield over a wide range of plant densities.

The present study showed that single soybean stems displayed low plasticity in response to canopy density. As density increased, the height of the lowest pod-setting node increased, while the number of nodes and the pod number per node significantly decreased (Rębilas et al., 2020). The productivity of the crop was determined by increased plant density, i.e. greater intraspecific competition, which stimulated plants to greater productivity. Contrasting results were obtained by Ferreira et al. (2016), who showed that the percentage of grain production in branches increases with decreasing plant densities.

According to Rahman and Hossain (2011), the optimal density of plants is often determined by local conditions, with a specific rainfall distribution. In the United States, the optimal density for soybean is $30-50$ plants $\mathrm{m}^{-2}$ (Grichar, 2007), while in India it is 4060 plants $\mathrm{m}^{-2}$, in Bangladesh 50-60 plants $\mathrm{m}^{-2}$, and in Kenya 45 plants $\mathrm{m}^{-2}$ (Rahman and Hossain, 2011; Bashar et al., 2019) Balbinot et al. (2018) conducted an experiment with soybean in Paraná, Brazil, and reported that at the lowest density yield was higher in the year with higher water availability. However, at densities of 23-44 plants $\mathrm{m}^{-2}$, yield did not vary between crop seasons. De Bruin and Pedersen (2008), who conducted an experiment in Iowa, USA, observed a higher capacity to increase yield at low densities, when water availability was favourable during the soybean development cycle.

In our research, seed yield was dependent on the interaction of weather conditions and plant density. In the dry year, no variability in yield was observed at a low plant density of 14-37 plants $\mathrm{m}^{-2}$. Yield increased as plant density increased above 37 plants $\mathrm{m}^{-2}$. In 
the wet year, optimum yields were obtained at a density of 35 plants $\mathrm{m}^{-2}$ and no increase in crop yield was observed above this density.

Balbinot et al. (2018) determined by a principal component analysis that the number of pods per plant on the branches and stems, the number of branches per plant, and the percentage of seed production from the branches are strongly associated with the phenotypic plasticity of the soybean plant. In our study, number of pods per plant and number of pods per shoot, root dry mass, root surface area, and root diameter were also indicative of the high plasticity of the plants, resulting in a lack of variation in features depending on the sowing density. Other features, such as aboveground biomass, number of shoots, and first pod height, exhibited variability depending on the density. The intensity of intraspecific competition was determined by the variation in individual plants in the canopy. At very low crop density, the intensity of intraspecific competition was very low, which blocked the manifestation of the plants' true production potential.

The $C I$ and $A S C$ indices are indicators of intraspecific and interspecific relationships in the canopy (Weigelt and Jolliffe, 2003). The competition indices increased with plant density, while relative yields $(R Y)$ decreased. According to Zhai et al. (2018), CI and $A S C$ reflect high intraspecific competition in plants. This was confirmed by our research, but only to a certain extent. The competition indices were very sensitive to the varying amount of rainfall available in the years of the study. Increased access to rainfall water during crop vegetation resulted in an increase in intraspecific competition accompanying increasing density, reaching a maximum at a density of 33 plants $\mathrm{m}^{-2}$. In contrast, the drought recorded in 2015 reduced intraspecific competition, eliminating it entirely at over 53 plants $\mathrm{m}^{-2}$.

\section{Conclusions}

The intensity of intraspecific competition was affected by weather during the years of the study, which demonstrates the low plasticity of soybean plants in the canopy.

Indices of intraspecific competition $(C I$ and $A S C)$ increased with plant density, while relative yields decreased.

Nitrogen uptake with seed yield is a result of two factors: water availability and plant density. In the dry year, nitrogen uptake increased with plant density in the canopy up to the maximum density. This suggests that in the event of drought stress, plants should be sown at a higher density.

\section{References}

Annicchiarico P, 2017. Feed legumes for truly sustainable cropanimal systems. Ital. J. Agron. 12:880.

Assefa Y, Prasad PVV, Carter P, Hinds M, Bhalla G, Schon R, Jeschke M, Paszkiewicz S, Ciampitti AI, 2016. Yield responses to planting density for US modern corn hybrids: A synthesisanalysis. Crop Sci. 56:2802-17.

Board JE, Kahlon CS, 2013. Morphological responses to low plant population differ between soybean genotypes. Crop Sci. 53:1109-19.

Bonser SP, 2013. High reproductive efficiency as an adaptive strategy in competitive environment. Funct. Ecol. 27:876-85.

Balbinot Junior AA, Neves de Oliveira MC, Franchini JC, Debiasi
H, Zucareli C, Ferreira A. S, Werner F, 2018. Phenotypic plasticity in a soybean cultivar with indeterminate growth type. Pes. Agr. Brasil. 53:1038-44.

Bashar HM, Khan MMH, Rahman MM, Rahaman F, Hussain J, Rokon GM, Shanto MH, Roy S, Akter N, 2019. Plant density effects on yield and yield attributes of two soybean varieties in Kharif-II Season of Bangladesh. Adv. Nut. Food Sci. 4:1-8.

Caratti FC, Lamego FP, Silva JDG, Garcia JR, Agostinetto D, 2016. Partitioning of competition for resources between soybean and corn as competitor plant. Planta Daninha, ViçosaMG, v. 34, n. 4, pp 657-665.

De Bruin JL, Pedersen P, 2008. Effect of row spacing and seeding rate on soybean yield. Agr. J. 100:704-10.

FAO, 2019. Food outlook. FAO, Rome, Italy. Available from: http://www.fao.org/3/ca6911en/CA6911EN.pdf

Ferreira AS, Balbinot Junior AA, Werner F, Zucareli C, Franchini JC, Debiasi H, 2016. Plant density and mineral nitrogen fertilisation influencing yield, yield components and concentration of oil and protein in soybean grains. Bragantia 75:362-70.

Grichar WJ, 2007. Row spacing, plant populations and cultivar effects on soybean production along Texas Gulf Coast. Crop Manag. 6:1-6.

ISTA, 2009. International Rules for Seed Testing. International Seed Testing Association, Geneva, Switzerland.

Klimek-Kopyra A, Bacior M, Zając T, 2017. Biodiversity as a creator of productivity and interspecific competitiveness of winter cereal species in mixed cropping. Ecol. Model. 343:123-30.

Luca MJ, Hungria M, 2014. Plant densities and modulation of symbiotic nitrogen fixation in soybean. Sci. Agric. 71:81-187.

Maddonni GA, Otegui ME, 2006. Intraspecific competition in maize: contribution of extreme plant hierarchies to grain yield, grain yield components and kernel composition. Field Crop Res. 97:155-66.

Neugschwandtner RW, Winkler J, Bernhart M, Pucher MA, Klug M, Werni C, Adam E, Kaul H-P, 2020. Effect of row spacing, seedling rate and nitrogen fertilisation on yield and yield components of soybean. Bodenkult. J. Land Manag. Food Env. 70:221-36.

Nicolin DJ, Jorge RMM, Jorge LMM, 2015. Moving boundary modelling of conventional and transgenic soybean hydration: Moisture profile and moving front experimental validation. Int. J. Heat Mass Transfer 90:568-77.

Nordby DE, Alderks DL, Nafziger ED, 2007. Competitiveness with weeds of soybean cultivars with different maturity and canopy width characteristics. Weed Technol. 21:1082-8.

Qian CR, Yang Y, Gong XJ, Jiang YB, Zhao Y, Yang ZL, Hao YB, Li L, Song ZW, Zhang WJ, 2016. Response of grain yield to plant density and nitrogen rate in spring maize hybrids released from 1970 to 2010 in Northeast China. Crop J. 4:459-67.

Rahman MM, Hossain MM, 2011. Plant density effects on growth, yield and yield components of two soybean varieties under equidistant planting arrangement. Asian J. Plant Spec. 10:278-86.

Rębilas K, Klimek-Kopyra A, Bacior M, Zając T, 2020. A model for the yield losses estimation in an early soybean (Glycine $\max ($ L. Merr.)) cultivar depending on the cutting height at harvest. Field Crop. Res. 254:107846.

Silverton J, Charlesworth D, 2001. Introduction to plant population biology. Blackwell Publishing, Hoboken, NJ, USA.

Snaydon RW, 1991. Replacement or additive designs for competition studies? J. App. Ecol. 28:930-46.

Snaydon RW, Satorre EH, 1989. Bivariate diagrams for plant competition data: modifications and interpretation. J App. Ecol. 26:1043-57. 
Spitters CJT, 1983. An alternative approach to the analysis of mixed cropping experiments. 1. Estimation of competition effects. Neth. J. Agric. Sci. 31:1-11.

Shapiro SS, Wilk MB, 1965. Ana analysis of variance test for normality (complete samples). Biometrika 52:591-611.

Visser CLM, Schreuder R, Stoddard F, 2015. The EU's dependency on soya bean import for the animal feed industry and potential for EU produced alternatives. OCL 21:1-8. Doi: 10.1051/ocl/2014021.

Vollmann J, 2016. Soybean versus other food grain legumes: A critical appraisal of the United Nations Interna-tional Year of Pulses 2016. Bodenkult. J. Land Manag. Food Env. 67:17-24.

Wang L-W, Showalter A, Ungar I, 2005. Effects of intraspecific competition on growth and photosynthesis of Atriplex prostrata. Aquatic Botant. 83:1870192.
Weigelt A, Jolliffe P, 2003. Indices of plant competition. J. Ecol. 91:707-20.

Werner F, Balbinot Junior AA, Ferreira AS, Silva MA, Debiashi H, Franchini JC, 2016. Soybean growth affected by seeding rate and mineral nitrogen. Revista Brasil. Eng. Agríc. Ambien. 20:734-8.

Yang X-Z, Zhang W-H, He Q-Y, 2019. Effects of intraspecific competition on growth, architecture and biomass allocation of Quercus Liaotungensis. J. Plant Int. 14:284-94.

Zhai LC, Xie R, Ming B, Li S, Ma D, 2018. Evaluation and analysis of intraspecific competition in maize: A case study on plant density experiment. J. Int. Agric. 17:2235-44.

Zhang Q, Li Y, Chin K, Qi Y, 2017. Vegetable soybean: Seed composition and production research. Ital. J. Agron. 12:872. 